\title{
Assessment of the Effect of Bank of Agriculture Loan on Female Farmers' Agricultural Production in Ekiti State, Nigeria
}

\author{
Owoeye, R. S. and Toluwase, S. O. W.
}

\begin{abstract}
The study assessed the effect of Bank of Agriculture (BOA) loan on female farmers' production in Ekiti State, Nigeria. A well-structured questionnaire was used to collect information from respondents in the study area through interview schedule. A multi-staged sampling procedure was used to select respondents for the study. Purposive sampling technique was used to select two (2) out of the three (3) Local Government Areas (LGAs) which BOA branches are established in Ekiti State i.e. Ado Ekiti and Ijero Ekiti. Then, 45 respondents were selected and interviewed, using convenience sampling in each of the LGA selected. In total, sample size of 90 respondents were interviewed for this study. Data collected were subjected to descriptive analysis, i.e. mean, percentage, frequency, standard deviation, minimum and maximum values were used to describe the socio-economic characteristics of the respondents. The result showed that the average age of the respondents was approximately 40 years and majority of the respondents (48.9 percent) had 7-12years of education. Also, 88.9 percent of the respondents had heard about BOA and 32.2 percent had received $\$ 50,000$ or less. Results further showed that $\mathbf{7 7 . 8}$ percent of the respondents experienced increase in production capacity while $\mathbf{5 8 . 9}$ percent of the total respondents experienced better standard of living. Result from Probit regression model showed that ownership of land, awareness of BOA, and past and current credit use had statistically significant effect on loan accessibility. It further showed that marital status, ownership of land, awareness, past and current credit use and collateral had positive effect on loan accessibility. Contrarily, age, educational level, income, membership of association were inversely correlated with loan accessibility. About 69 percent of the respondents were faced with the challenges of need for guarantor, 61.1 percent of the respondents faced with the problem of bureaucracy i.e. unnecessary delay in provision of the loan, while 46.7 percent had challenges due to the location of $\mathrm{BOA}$ branches. It is therefore recommended that government should include access to credit in any agricultural development programs in Nigeria, and provide funds to BOA so as to reduce bureaucracy in loan disbursement. Also, Women farmers should be encouraged and educated by extension workers to belong to cooperative associations so as to enjoy benefits emanating from being members of agricultural association.
\end{abstract}

Index term-Bank of Agriculture, Female Farmers, Probit Regression

\section{INTRODUCTION}

Agriculture is the bedrock of economic growth, development and poverty eradication in the developing countries. Agriculture has also been regarded to as the engine and panacea to economic prosperity. The agricultural sector provides job opportunities and raw materials for many agroallied industries. The importance of agricultural development to socio-economic growth and development in many third world countries is keen on their transition to economic prosperity. Agriculture contributes over one quarter of the GDP in the most developing nations of the world, especially in Nigeria. [1].

The National report for 2004 United Nations Conference on Environment and Development indicates that at least $40 \%$ of Agricultural production activities and $85 \%$ of agricultural produce, processing and marketing are performed by women. Women have a predicament that is quite appalling, they constitute the majority of the poor and the illiterate in both urban and rural areas in Nigeria, whose productive roles are regarded as part of their domestic roles, categorized as a homogenous group distinguished only by their gender. Men still make most of the key management decisions despite the fact that women make up to 60 to $80 \%$ of the agricultural labour force in Nigeria and produce two third of the food crops. Women are most times ignored, underestimated and voiceless in influencing production and management decisions even within the household [2].

Women make up 60 to $80 \%$ of the agricultural labour force in Nigeria and produce two third of the food crops. They face severe constraints than men in accessing productive resources including markets, credit, education and training, lack fund to expand their business and support services such as agricultural extension services. Although the participation of rural women in agricultural production at the household level is higher and they spend more time than men in agricultural related activities, their work has not been recognized both at the national and international levels [3].

They are faced with problems like inability to access loan from non-agricultural banks due to unnecessary bureaucracy/ delay, high interest rate, lack of collateral among others. When women lack access to land, they are not eligible for credit, membership of farmers' organizations, extension training and services [4], their heavy workloads and lack of improved inputs also hinder them. National development is being hampered by excluding the perspectives, skills, capabilities and dynamism of half the population seeing that women constitute a crucial group in the productivity equation [5].

Farming like every other business requires Capital which is needed for various production resources and efficient combinations of the resources. Financing agriculture either in cash or kind had ranged from family, individual savings and gifts, private money lenders, daily contributions, cooperative thrift associations, cooperative societies, produce buyers to state agricultural credit corporations and agencies agricultural development agencies etc. [6]. 


\section{A. Study Area}

\section{METHODOLOGY}

The study was conducted in Ekiti State, Nigeria. The State is within the tropics, and it was created on the 1st of October, 1996 and comprises of 16 Local Government Areas (LGAs). Ekiti State occupies land mass of approximately $6,6028 \mathrm{~km}^{2}$ and a population of 2,384,212 (NPC, 2006).

It is located between longitude $7^{\circ} 45$ and $5^{\circ} 45$ East of the East of the Greenwich meridian and latitudes $7^{\circ} 45$ East and $8^{\circ} 5$ North of the equator. Ekiti State is bounded in the North by Kwara and Kogi States, in the south by Ondo State, in the west by Osun State and in the East by Ondo - State. Ekiti State has a mean annual rainfall of about $1400 \mathrm{~mm}$ and a mean annual temperature of about $27^{\circ} \mathrm{C}$. Its vegetation ranges from rain forest in the south to guinea savannah in the North with soil largely rich in organic minerals thereby making the State a major producer of tree and food crops. According to 2006 population and housing census, the State has 2.5 million people and is made up of predominantly the Yoruba ethnic groups with a few other ethnic groups that have settled in the State. Majority of the people in the study area are peasant farmers who live in rural community settings. They are closely related in tradition and culture, speaking the same language with minor dialectal differences. For this reason, Ekiti State has been described as unique in composition as it is the only State in Nigeria with homogenous ethnic group. The state has two main seasons i.e. the rainy season and dry season. The major occupation among the inhabitants of Ekiti State is farming. They produce crops like rice, kolanut, oil palm, and cocoa. They also produce cassava, yam, cocoyam, maize, cowpea, citrus, plantain, mango, and cashew with reasonable percentage of them engaging in other forms of occupation such as trading, weaving and hand craft etc. hence Ekiti State is predominantly agrarian in nature [7].

\section{B. Sampling Techniques and Sampling Size}

A multi-stage random sampling technique was used to select respondents for this study. At first stage, purposive sampling technique was used to select two (2) of the three (3) Local Government Areas of which BOA branches are established in Ekiti State, which are Ado Ekiti and Ijero Ekiti in Ekiti state. At the second stage, 45 respondents was selected using convenience sampling and interviewed in each of the Local Government selected because not all the respondent found it convenient to give response to the questionnaires. In total, sample size of 90 respondents were interviewed for this study. Primary data was used for the study. Data were collected from the respondents with the aid of well-structured questionnaire, interview schedule and observation of the respondents.

\section{Data Analysis \\ Descriptive Statistics}

Descriptive statistics such as frequency, percentage, mean and so on were used to; describe the socio-economic characteristics of female farmers in the study area, describe the effects of loan accessibility on respondents and also to identify constraints faced by respondents in the study area.

\section{Probit Regression}

This was used to examine the factors affecting the access of respondents to financial loans in the study area.
For the probit models, we assume an individual is faced with two alternatives, either they have accessed loan or not. This is expressed as [8].

We assume $\mathrm{Y}$ can be specified as follows:

$\mathrm{Y}=\beta_{0}+\beta_{1} \mathrm{X}_{1}+\beta_{2} \mathrm{X}_{2}+\ldots \ldots \ldots \ldots \ldots \ldots+\beta_{\mathrm{n}} \mathrm{X}_{\mathrm{n}}+\mathrm{U}_{\mathrm{i}}$

And that: $Y_{i}=1 \quad$ if $Y>0$

$\mathrm{Y}_{\mathrm{i}}=0$ Otherwise,

Where $\mathrm{X}_{1}, \mathrm{X}_{2} \ldots \ldots \ldots \ldots \ldots \ldots \ldots \mathrm{X}_{\mathrm{n}}$ represent vector of random variables, $\beta$ represent a vector of unknown parameters and

$\mathrm{U}_{\mathrm{i}}$ represent a random disturbance terms (Nagler, 1994)

The probit model specified in this study was to evaluate the factors that affected accessibility or non-accessibility of loan can be expressed as follows:

$\mathrm{Y}_{\mathrm{i}}=\beta_{0}+\beta_{1} \mathrm{X}_{1}+\beta_{2} \mathrm{X}_{2}+\beta_{3} \mathrm{X}_{3}+\beta_{4} \mathrm{X}_{4}+\beta_{5} \mathrm{X}_{5}+\beta_{6} \mathrm{X}_{6}+\beta_{7} \mathrm{X}_{7}+\beta_{8} \mathrm{X}_{8}+\beta_{9} \mathrm{X}_{9}+$ $\mathrm{U}_{\mathrm{i}}$

Where Yi = Loan Accessibility (Yes (1), No (0))

$\mathrm{X}_{1}=$ Age (Years)

$\mathrm{X}_{2}=$ Educational level (Years)

$\mathrm{X}_{3}=$ Marital status $($ Married $=1$, otherwise $=0$ )

$\mathrm{X}_{4}=$ Land Ownership (Sole proprietor $=1$, otherwise $=0$ )

$\mathrm{X}_{5}=$ Income ( $)$

$\mathrm{X}_{6}=$ Membership of association (cooperative $=1$, otherwise $=$ $0)$

$\mathrm{X}_{7}=$ Awareness of BOA $($ yes $=1$, otherwise $=0)$

$\mathrm{X}_{8}=$ Past and Current Credit use (

$\mathrm{X}_{9}=$ Collateral (Number)

$\mathrm{Ui}=$ Error term.

$\mathrm{U}_{\mathrm{i}}$ is the residual error, which is normally distributed with the expected mean value of zero and variance $\left(\boldsymbol{\sigma}^{2} \mathrm{x}\right)$. This study examines this model by the measurement of all the variables and estimation of their parameters.

\section{RESULTS AND DISCUSSIONS}

\section{A. Socio-Economic Characteristics of the Respondents}

The Table 1 below showed the socio-economic characteristics of the respondents in the study area. From the percentage distribution, it showed that the respondents between the ages of 31-40 had majority of the beneficiaries with 38.9 percent. Educational qualification of the respondents showed that majority of the respondent (48.9 percent) had 7-12 years of education, and 28.9 percent for those that had 13-16 years of education. The respondents had a mean educational level of approximately 10 years. Marital status distribution of the respondents showed that 67.8 percent of the respondents were married, and only 7.8 percent of the respondents were divorced. Distribution of respondents by annual income showed that only 4.4 percent of the respondents in the study area earned less than $\$ 100,000$ and 10.0 percent earned over $\$ 1,000,000$. The table showed that most of the respondents (32.2 percent) acquired their land by inheritance and 27.8 percent through purchase while 12.2 percent of the respondents acquired their lands through rent. Distribution of respondents by the association type they belonged to showed that 67.8 percent of the total population belonged to cooperative society, 20 percent belonged to religious society. Also, 8.9 belonged to produce association group, and only 3.3 percent of the respondents did not belong to any group. The table also showed if the respondents have heard of the Bank of Agriculture, BOA. It was gathered that 88.9 percent of the respondents have heard about BOA and only 11.1 percent of them have not heard about BOA. 
Distribution of respondents by "how much they received as credit" showed distribution of the respondents based on the amount they had received from BOA as credit. The percentage distribution showed that 32.2 percent of the respondents had received $\$ 50,000$ or less, it was gathered during the interview that some of the respondents were yet to receive the loan they applied for. Also, 14.5 percent of the respondents had received $\$ 51,000-100,000$, and majority (38.9 percent) received 101,000-300,000, also, 60 percent of the respondents received extension visit on monthly basis.

\section{TABLE 1: SOCIO-ECONOMIC CHARACTERISTICS OF THE RESPONENTS}

\begin{tabular}{llll}
\hline \hline Variables & Frequency & Percentage & Annua \\
& & \\
\hline
\end{tabular}

$\leq 30$

$31-40$

$41-50$

$51-60$

Above 60

Mean

Educational Level

$\leq 6$

7-12

13-16

$>16$

Mean

Marital Status

Single

Married

Divorced

Widow

Household Size

$\leq 3$

4-6

7-9

$>9$

Mean

Production Type

Arable Crop

Cash Crop

Poultry

Small Ruminant

Association Type

No Group

Coop. Society

Produce Ass.

Religious Soc.

Sources of Credit

Agric. Bank

Comm. Bank

Coop. Society

Money Lender

Others

Extension Services

Fortnightly

Monthly

Every 3 Months

Every 6 Months

Not at all
Age (years)
17.8

38.9

34.4

7.8

1.1

40.2

7

20.0

48.9

28.9

2.2

10.8

2

17

18.9

67.8

7.8

5.5

13.3

72.3

13.3

1.1

5

\section{Credit Received (}

$0-50,000$

$51,000-100,000$
29

13
32.2

14.4

\begin{tabular}{|c|c|c|}
\hline Variables & Frequency & Percentage \\
\hline $101,000-300,000$ & 35 & 38.9 \\
\hline $301,000-600,000$ & 9 & 10.0 \\
\hline$>600,000$ & 4 & 4.4 \\
\hline \multicolumn{3}{|c|}{ Mean $180,555.5$} \\
\hline Fish Production & 10 & 11.1 \\
\hline Pig Production & 9 & 10.0 \\
\hline = Others & 4 & 4.4 \\
\hline \multicolumn{3}{|l|}{$\overline{\overline{A n n}}$ Anual Income } \\
\hline$\leq 100,000$ & 4 & 4.4 \\
\hline $101,000-500,000$ & 58 & 64.5 \\
\hline $501,000-1,000,000$ & 19 & 21.1 \\
\hline$>1,000,000$ & 9 & 10.0 \\
\hline \multicolumn{3}{|c|}{ Mean $\quad 610,766.56$} \\
\hline \multicolumn{3}{|c|}{ Other Income Activities } \\
\hline Trading & 46 & 51.1 \\
\hline Civil Services & 18 & 20.0 \\
\hline Artisanal Jobs & 14 & 15.6 \\
\hline Others & 12 & 13.3 \\
\hline \multicolumn{3}{|l|}{ Farm Size } \\
\hline$\leq 1$ & 59 & 65.6 \\
\hline $1-5$ & 27 & 30.0 \\
\hline$>5$ & 4 & 4.4 \\
\hline \multicolumn{3}{|c|}{ Mean 0.79} \\
\hline \multicolumn{3}{|c|}{ Mode of Land Acquisition } \\
\hline Inheritance & 29 & 32.2 \\
\hline Purchase & 25 & 27.8 \\
\hline Family & 24 & 26.7 \\
\hline Rent & 11 & 12.2 \\
\hline Others & 1 & 1.1 \\
\hline
\end{tabular}

Source: Computed from field survey, 2018

\section{B. Effects of BOA Loan on Farmers' Income Distribution}

The table below showed the distribution of the respondents based on the effects of BOA loan on them. The study revealed that 77.8 percent of the respondents claimed that they experienced increase in production capacity; this means that the loan accessed by respondent helped them in increasing their scale of production. The result further revealed that 58.9 percent of the respondents experienced a better standard of living, this means that the use of the loan accessed translated to higher resource employment and capacity utilization, increased output and income, reduced poverty among respondents. This means it also led to improvement in their welfare and consequently reduction in poverty and food insecurity levels.

Also, 55.6 percent of the respondents were able to manage their financial distress as a result of obtaining the loan, that is, they agreed that the accessed loan helped them in managing financial instability that occurs during agricultural production as a result of demand for factors of production; 47.8 percent were able to access input for production easily, agricultural production is based on use of inputs, timely and properly, usage of input is very important to get a better production, the result showed that 47.8 percent of the respondent agreed that they were able to access input easily as 
a result of accessed loan; and 45.5 percent enjoyed timely information on production and ways of improving it, that is aside from financial benefits, they also enjoyed advisory purposes from BOA.

It further showed that 38.9 percent were able to produce easily thereby leading to food security, 34.4 percent were able to manage large on-going debt as there was no credit constraint in their production while 23.3 percent enjoyed extension service and training and only 20 percent had effective market entry since they were able to produce regularly. Access to credit is also considered to be an important tool for smoothing consumption and promoting production especially for poor households (e.g. Swain et al., 2008). This means that access to credit can significantly increase the ability of households with no or few savings to meet their financial needs for agricultural inputs. This also means that the respondents had in one way or the other benefited from the services of BOA

TABLE 2: DISTRIBUTION OF EFFECTS OF BOA LOAN ON THE FEMALE FARMERS

\begin{tabular}{lll}
\hline \multicolumn{1}{c}{ Benefits } & Frequency & Percentage \\
\hline & & \\
Increase in production & 70 & 77.8 \\
Capacity & 53 & 58.9 \\
Better standard of living & 50 & 55.6 \\
Manage financial distress & 43 & 47.8 \\
Easy access to input & 41 & 45.5 \\
Timely information & 35 & 38.9 \\
Ease of production & 31 & 34.4 \\
Manage large on-going debt & & \\
Extension service and & 21 & 23.3 \\
training & 18 & 20.0 \\
Effective market entry & & \\
\hline
\end{tabular}

\section{Source: Computed from field survey, 2018}

\section{Factors Affecting Access of Respondents to Financial Loan in the Study Area.}

The section presents the results of the probit model that showed how socio-economic characteristics of respondents affected their access to financial loan by BOA. Accessibility was measured in terms of the socio-economic characteristics of the respondents. The likelihood estimates of the probit model indicated that the chi square $\left(x^{2}\right)$ statistic of -38.369954 was significant $(\mathrm{P}<0.0001)$ suggesting that the model has a strong explanatory power. The pseudo coefficient of multiple determinations $\left(\mathrm{R}^{2}\right)$ showed that $30 \%$ variation in the dependent was explained by the included independent variables. This implies that the model showed a good fit to the data.

The results revealed that past and current credit use, ownership of land and awareness of BOA were all statistically significant at $1 \%$ respectively. This implies that they were found to significantly influence the accessibility of loan in the study area. The results suggest that for every 1 unit increase in the variables, there is probability of increase in the access to loan. Also, all the positively signed independent variables implied that a unit increase in those variables brings about increase in the level of loan accessibility, and vice-versa.

\section{TABLE 3: PROBIT ESTIMATES OF FACTORS INFLUENCING LOAN ACCESSIBILITY}

\begin{tabular}{lll}
\hline \hline Explanatory Variables & Coefficient & P-value \\
\hline Age & 0.0180 & 0.376 \\
Educational level & 0.0075 & 0.879 \\
Marital Status & 0.4233 & 0.247 \\
Ownership of Land & $1.005^{* * *}$ & 0.003 \\
Income & 6.5701 & 0.787 \\
Membership of Association & -0.2802 & 0.747 \\
Awareness of BOA & $1.8334 * * *$ & 0.001 \\
Past and current Credit use & $1.0777^{* * *}$ & 0.001 \\
Collateral & 0.3988 & 0.211 \\
Constant & 1.0641 & 0.395 \\
LR Chi square $=33.22$ & & \\
Pseudo R ${ }^{2}=0.3021$ & & \\
Prob $>$ chi square $=0.00014$ & &
\end{tabular}

Source: Computed form field survey, $2018, * * *=1 \%$ level of significance.

\section{Distribution of Respondents' Challenges in Accessing Loan}

The table below showed the various challenges faced by the respondents while accessing the loan from BOA. The percentage distribution showed that 68.9 percent (majority) of the respondents were faced with the challenges of need for guarantor. This means that most of the respondents' applications were delayed because they needed guarantors. Also, 61.1 percent of the respondents faced with the problem of bureaucracy that is, unnecessary delay in provision of the loan.

Also, 46.7 percent had challenges due to the location of BOA branches, it was gathered during the interview that the location of branches were not convenient for some of the respondents in the study area. The result further showed that 43.3 percent of the respondents did not have sufficient information on availability of loan. It further revealed that 41.1 percent were not able to obtain the loan due to fear of repayment; they claimed that getting the loan gives them certain kind of fear of having to pay the loan back while 34.4 percent were faced with lack of market for their produce, 24.4 had lack of zeal, and 23.3 percent of the respondents were faced with poor reception. Only 16.7 percent of the respondents had challenges due to illiteracy. 
TABLE 4: DISTRIBUTION OF RESPONDENTS BY CONSTRAINTS THEY FACED WHILE ACCESSING LOAN

$\begin{array}{lll}\text { Constraints } & \text { Frequency } & \text { Percentage }\end{array}$

Need for guarantor

62

Bureaucracy

55

42

Location of bank branches

39

Insufficient information

37

Fear of repayment

31

Produce of products

Lack of collateral

Lack of passion

Inflexible payment schedules

Loan siphoning

Deprivation due to gender

Fluctuation in production

16

Illiteracy

15

Others

15 16.7

\section{Multiple responses}

Source: Computed from field survey, 2018

\section{CONCLUSION AND RECOMMENDATIONS}

In conclusion, the socio-economic result showed that, the respondents were willing to produce and obtain loan from BOA, since they were within the productive and economic active age which means they were capable to provide adequate food quantity needed by the households. They can read and write, and with that it will be easier to access loans and other benefits from BOA. The respondents in the study area preferred and felt more comfortable to obtain loan from agricultural banks, cooperatives and even local money lenders compared to commercial bank loans. The respondents had in one way or the other benefitted from the services of BOA, getting loan from BOA was possible for respondents in the study area and not illusionary.
The study further concluded that ownership of land, awareness of BOA, and past and current credit use were the determining factors for loan accessibility in the study area while the female farmers were confronted with challenges such as; need for guarantor, bureaucracy, the location of branches were not convenient for some of the respondents in the study area

Based on the findings of this study, it is therefore recommended that;

Government should include access to credit in any Agricultural development programs in Nigeria, and provide funds to BOA so as to reduce bureaucracy in loan disbursement.

- Women farmers should be encouraged and educated by extension workers to belong to cooperative associations so as to enjoy benefits emanating from being members of agricultural association.

- The women should also be encouraged to patronize BOA by developing a good, educative, informative and socially acceptable public awareness for financial benefit offered by BOA and they should be provided with timely and adequate information.

- Government should also encourage young and productive female farmers to engage in agricultural production, and increase their production capacity by obtaining credit.

- The number of branches of BOA can also be increased in order to make it convenient for people to locate and patronize BOA.

\section{ACKNOWLEDGEMENTS}

The authors would like to thank Mr. Oladele and Joshua of Bank of Agriculture, Ado Ekiti Branch, Nigeria. Also worthy of appreciation is Miss Olawale Abosede Olawumi who played vital roles during data collection for this study. Comments and suggestions of the anonymous reviewers are appreciated

\section{REFERENCES}

[1] Kamil, S., Sevin, U., and F. V., Bekun (2017). "The Contribution of Agricultural Sector on Economic Growth of Nigeria", International Journal of Economics and Financial Issues, 7 (1), pg. 547-552

[2] Ogunlela, Y. I. and Muktar, A. A. (2009). "Gender Issues in Agriculture and Rural Development in Nigeria- The Role of Women", Humanity and Social Sciences Journal 4 (1) 19-30

[3] Njoki, J. N. (2014). "Challenges Women Farmers Face in Accessing Agricultural Extension Services, in Kamugere Sub Location of Embu County", African Journal of Agricultural Research, vol.4 (12), pp. 1404-1409.

[4] ICRW (2012) "Child Marriage in Southern Asia: Context, Evidence and Policy Options for Action. Rep", International Center for Research on Women (ICRW)

[5] Emansion, A. (2012). On Agriculture and Food Security; Launches Initiative to Empower Women in Agriculture.[Internet] Available at:http://www.emansion.gov.lr/press.php?news_id=2258

[6] Famogbiele, A. (2013). "The Challenges of Agricultural Finance in Nigeria: Constraints to Sustainable Agricultural and Economic Revival", International Journal of Business and Social Research (IJBSR), Volume 3(5), Pg. 234-244.

[7] Owoeye, R. S. and S. O. W. Toluwase (2018). "Factors Influencing Resource Use Efficiency Differentials of Farm Size among Cassava Farmers in Ekiti State, Nigeria", Asian Journal of Advances in Agricultural Research Vol. 5(2): 1-7. Article no.AJAAR.38249 ISSN: $2456-8864$ 
[8] Nagler, J. (1994). "Interpreting Probit Analysis", New York University
Press,
[Online],
pp. $\quad 1-15$.
Available:

webpage:www.nyu.edu/classe/nagler/quantz/notes/probit1.pdf.

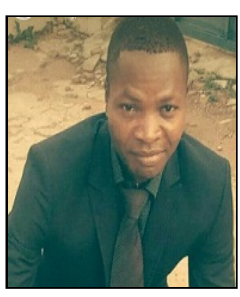

Dr. Owoeye, R. S. was born in Iworoko Ekiti, Nigeria on August $8^{\text {th }}, 1980$. He finished his Master's Degree in Agricultural Economics at Federal University of Technology, Akure, Nigeria in 2014. Thereafter, he proceeded to pursue his Ph.D Degree in the same University between 2015-2019. He was fully employed in 2017 at Ekiti State University, Ado Ekiti, Nigeria to teach, conduct researches and engage in community development projects. He specializes in Agricultural Production Economics, Resource Economics and Environmental Economics. He has reviewed and published many Agriculturerelated articles both in local and international journal 
EJFOOD, European Journal of Agriculture and Food Sciences

Vol. 2, No. 1, January 2020 